\title{
Purposes in life of young Brazilians: identities and values in context
}

\author{
Projetos de vida de jovens brasileiros: \\ identidades e valores em contexto
}

\author{
Valéria Amorim ARANTES ${ }^{1}$ iD 0000-0002-2154-6147 \\ Viviane Potenza Guimarães PINHEIRO' ${ }^{1}$ (iD) 0000-0003-4305-1089
}

\begin{abstract}
The aim of the article was to analyze the purposes in life of young Brazilians. A total of 560 students, aged 15-19 years, from the five geopolitical regions of Brazil, answered an open questionnaire developed by the Stanford Center on Adolescence and adapted to the specificities of the research. The data were analyzed using the Theory of Organizing Models of Thinking, which enabled us to identify six models of purposes. Most young people expressed their life purposes as a natural course of life or as an idealized dream; most of them also presented a self-centered view of their purposes, focused on their own accomplishments. The results reveal an association between life purposes and identity of young Brazilians in the interaction with collective values, particularly regarding the overcoming of economic difficulties and financial achievements.
\end{abstract}

Keywords: Brazilian youth; Organizing models of thinking; Purpose.

\section{Resumo}

O artigo tem como objetivo analisar os projetos de vida de jovens brasileiros. Quinhentos e sessenta estudantes, com idade entre 15 e 19 anos, representantes das cinco regiões geopolíticas do Brasil responderam um questionário aberto formulado pelo Stanford Center on Adolescence e adaptado aos propósitos do trabalho. Os dados foram analisados por meio da Teoria dos Modelos Organizadores do Pensamento e permitiram a identificação de seis formas de projetar o futuro. Observou-se que a maioria dos jovens entende seus projetos de vida como um curso natural da vida ou como um sonho ou idealização, assim como apresentam uma visão de futuro altamente centrada no eu e em suas próprias conquistas. Os resultados evidenciam a articulação da construção dos projetos de vida dos jovens brasileiros à formação de suas identidades na interação com os valores coletivos, em especial em relação à superação de dificuldades econômicas e a conquistas financeiras.

Palavras-chave: Jovens brasileiros; Modelos organizadores; Projeto de vida.

\footnotetext{
$\boldsymbol{V V} \mathrm{V}$

1 Universidade de São Paulo, Faculdade de Educação, Departamento de Filosofia da Educação e Ciências da Educação. Av. da Universidade, 308, Cidade Universitária, 05508-900, São Paulo, SP, Brasil. Correspondence to: V.A. ARANTES. E-mail: <varantes@usp.br>.

How to cite this article

Arantes, V. A., \& Pinheiro, V. P. G. (2021). Purposes in life of young Brazilians: identities and values in context. Estudos de Psicologia (Campinas), 38, e200012. https://doi.org/10.1590/1982-0275202138e200012
} 
The concept of purpose has received great attention in the field of psychology, both internationally and nationally. Studies such as those by Dellazzana-Zanon and Freitas (2015), Kosby and Mariano (2011), Mariano and Going (2011), and Winters, Leite, Pereira, Vieira, and Dellazzana-Zanon (2018) address, through literature reviews, how the concept has been understood from different perspectives in articles, contributing to the perception that the growing interest in the theme and the consequent increase in the number of studies is proportional to the opening of new research fields and the diversity of theoretical understandings.

Despite the divergences and contradictions regarding the concept of purpose, studies by Winters et al. (2018), for example, point to a predominance of the definition presented by Damon, Menon, and Bronk (2003, p. 121): "Purpose is a stable and generalized intention to accomplish something that is at the same time meaningful to the self and consequential to the world beyond-the-self". This theoretical construct, named purpose, has been a source of studies at the Stanford Center on Adolescence, led by Prof. Willian Damon, since the 90s, which is based on the principle highlighted by Frankl (1946/1991) that the search for meaning in life is the primary motivating force in human beings. Thus, gaining momentum from the framework of positive psychology, which reinforces the study of the strengths and virtues of human beings (Seligman \& Csikszentmihalyi, 2000), investigations on the purpose in life aim to understand how people, through meaningful goals, can become psychologically healthy, based on the feeling of accomplishment and the idea that they are not only surviving, but living and thriving in the way they have envisioned (Bronk, 2014; Kosby \& Mariano, 2011; Mariano \& Going, 2011).

In portuguese, the introduction of the concept of purpose in life as "propósito" seems to bring some weaknesses and/or theoretical misunderstandings that may lead to the idea of a universal process that is decontextualized and not subject to changes. Araújo (2009) had previously advised of the risks of translating the term purpose and pointed out the importance of maintaining its immanently human characteristic and, consequently, its ethical implications, defending the adoption of the term "projeto de vida", in Portuguese literature, as the meaning for purpose.

It is, therefore, important to resume this concept in psychology studies, based on the concept of Damon et al. (2003), to arrive at a more in-depth conceptualization, which allows us to analyze, within the scope of our research, how young Brazilians organize their thinking in relation to their purposes in life.

\section{The concept of purposes in life}

Purposes in life are, above all, a psychological organizational principle that provides people with a vision of their future in a coherent and meaningful way regarding their present life and history (Kosby \& Mariano, 2011). It can be understood as an inner strength that organizes, motivates and drives short- and long-term plans, behaviors and goals (Damon, 2009; Kashdan \& Mcknight, 2009), outlining a life trajectory that is built on exchanges between the individual and life contexts (Malin, Reilly, Quinn, \& Moran, 2013; Malin, 2018). In this sense, a person can have (and usually has) more than one purpose in life (Bronk, 2014; Bundick, 2011; Malin, 2018), combining several purposes at the same time or going through different purposes throughout life. The sense of direction of a purpose is abstract and, therefore, generalizable; not ephemeral, but stable for long enough to guide and organize actions; and highly significant and motivating for the individuals who combine long-term goals with multiple concrete goals (Bronk, 2011, 2014; Bundick, 2009).

Contemporary studies on purposes point to three central aspects for their definition: intention(s) concerning the future, significant engagement to achieve what is intended and the desire to connect and contribute to the world beyond-the-self (Bronk, 2012, 2014; Malin et al., 2013; Malin, 2018). Intentions are what individuals wants to accomplish in one's future life, that is, one's life goals. These goals are related

2 to the content of purposes, such as becoming a doctor, becoming responsible for a family, or working in 
an Non-governmental Organization to care for children in poverty. As suggested by Malin et al. (2013), the interactions that the individuals establish with the contexts of their experience are important for the development of their future intentions, since they are based on social norms to outline goals and evaluate their own success (or failure) in achieving them.

A future intention that is not driven by present attitudes and short-term goals, in fact, results in dreams and idealizations (Damon, 2009). Therefore, for significant purposiveness, engagement is required, which is manifested by the individual's commitment to their life purposes (Bronk, 2011; Bundick, 2009). Engagement refers to action in and within the socio-cultural context, according to their intentions, providing the feeling of a "meaningful" life (Frankl, 1946/1991).

The desire to contribute to the world beyond the self articulates one's intentions to a meaningful engagement (Damon et al., 2003; Damon, 2009). Malin et al. (2013) highlight that the beyond-the-self dimension distinguishes goals that guide and organize purposes from those that provide only personal satisfaction. Having a sense of fulfillment, a personal satisfaction, is an important step to achieving purpose. However, pursuing only pleasure and only having self-centered goals contributes to the creation of an existential void that can have negative consequences, such as depression and drug addiction (Frankl, 1946/1991). The desire to connect with the world and to contribute to something greater than the self does not replace highly self-centered interests and desires. Our understanding, due to the complexity of the human psyche, is that intentions, objectives, and goals as well as the motivation and commitment to achieve them, fit both perspectives. Furthermore, in individuals who combine intentions and engagement beyond themselves, it is expected that the organization and direction provided by purposes combine 'self-oriented' and 'beyond-theself' dimensions in many aspects of life (Bronk, 2012; Colby \& Damon, 1992; Malin et al., 2013).

The dimension of desire to connect with and impact the world beyond-the-self may give the impression that having a purpose in life is possible for few people. On the contrary, fostering purposes is an attainable task as it requires no special resources or privileges (Malin, 2018). As Bundick (2009) has pointed out, when setting goals, within any content (and not necessarily from an altruistic source), that organize and motivate meaningful engagement, individuals act in contexts and cause a social impact even if, initially, that was not their intention. Therefore, purposes can have any content, as long as they provide the individual with the sense that their life is meaningful and important for themselves and for others (Damon, 2009).

\section{Youth purposes}

There is a reasonable consensus in the literature when considering adolescence and early adulthood as the moment when individuals can consider and commit themselves to purposes (Bronk, 2014; Malin et al., 2013). This stage is characterized as a psychological, biological, social, and cultural framework, in which individuals open themselves to the world, become more aware and come to understand themselves as social agents.

According to Erikson $(1968,1980)$, adolescents and young adults experience different roles and explore different personalities to determine who they are and how they fit into the world beyond-the-self. Identity formation embraces a process in which individuals gradually attribute personal meaning to each component of life, understanding and committing themselves to their own values and beliefs.

This process is linked to the development of purpose since it requires decentralizing the self to align with social possibilities and expectations. Engaging in meaningful activities is at the core of the one's development of purpose. By assigning meaning to the environment, individuals can perceive their place in the world and the meaning apprehended by this movement corroborates both their identity formation, and the development of purpose in life (Parks, 2011). 
Identity formation and the development of purpose are, therefore, highly related processes, as they share the individuals' beliefs, values, and goals. However, although they are evidenced at the same stage of life and share the same focus, they are different constructs. Identity refers to who we want to be, while purpose refers to what we want to achieve and why (Bronk, 2011). Thus, all young people develop their identity, but not all of them find purposes that ensure them meaningful paths (Moran, 2009).

The association between identity and purpose comes from a complex, multidimensional and dynamic process. The particularities of this association occur in the interactions that individuals establish with social contexts, in a unique life trajectory. Brazilian studies on life purposes have shown that people project their future based on who they are, their values, beliefs and feelings (Danza, 2014, Gonçalo, 2016; Gomes, 2016; Pátaro, 2011; Pinheiro, 2013 and among others). The goals outlined by young people, depending on the positive affective projection they receive, correspond to their values, generating coherence between what one is and what one intends to become (Pinheiro \& Arantes, 2015). The uniqueness of each trajectory, built and projected during social interactions, highlight the multiplicity of possibilities for youth purposes and shows us that youth is not restricted to the experience that contemporary individuals experience in an intersubjective way, but also how each young person has unique and particular experiences at this stage of life (Arantes, Danza, Pinheiro, \& Pátaro, 2016). At the same time, the sociocultural dimension, that is, the contextual assets in which purposes are fostered, outline opportunities to youth engagement and goal achievements (Velho, 1994).

To analyze purpose is to analyze its dimensions, its interconnectivity to identity formation and, above all, its complexity; therefore, we reject constructs that reduce it and over simplify it. The aim of this article was to analyze the purposes of young Brazilians within this perspective, considering their particularities and regularities. Thus, we expect to strengthen the theoretical construct as an important contribution to understanding the trajectories of young Brazilians as well as contribute to the opening of new investigations in the area.

\section{Method}

The present study consists of five investigations, two Master's dissertations, two doctoral dissertations and one post-doctoral thesis (Arantes, 2012; Danza, 2014; Gonçalo, 2016; Gomes, 2016; Pinheiro, 2013), developed under the supervision of the first author between 2009 and 2017 . The qualitative analysis of the data aimed to consolidate the results found in these research studies as well as to outline a profile of the life purposes of young Brazilians. A total of 560 young Brazilians aged 15-19 years, from the five geopolitical regions of Brazil, participated in the study. In each region, data were collected from two types of municipality: metropolises (Belém, Fortaleza, Goiânia, São Paulo and Curitiba) and regional capitals (Macapá, Crato, Sobral, Dourados, Sumaré, Rio Claro, Ponta Grossa). Of these participants, $80 \%$ lived in low socioeconomic areas on the periphery of urban centers and $20 \%$ were students from private schools with medium-high socioeconomic status. The gender variable was controlled to balance the number of female and male participants.

These studies aimed to analyze youth purposes by using the Theory of Organizing Models of Thinking (Moreno-Marimón, Sastre, Bovet, \& Leal, 1998), using the same instrument, the same procedures for data collection, and the same steps for analysis. The common instrument was the internationally consolidated interview script (Andrews et al., 2006) developed by the Stanford Center on Adolescence, which was adapted for the investigations. The interview, consisting of 13 questions, on purposes and feelings attempts to create a multidimensional snapshot of each interviewee. It seeks to identify some aspects of the young participants' self, and to investigate changes they would like to occur in the world (seeking to characterize their ideal world), to analyze their future intentions, and to identify their life purposes. Data from all studies were collected in 
person (with the collaboration of the authors) at the selected schools by contacting representatives from the State Department of Education in each region.

\section{Data analysis}

The data analysis process was based on the theoretical and methodological assumptions adopted by the Theory of Organizing Models of Thinking. It consisted of four stages: in the first stage, an individual analysis of content of each protocol was carried out, aiming to raise the central elements, and obtaining a general overview about each young person's life purposes. By doing so, a form was generated for each participant, which enabled a comprehensive and complete reading of their responses. In the second stage, once the material had been organized, individual analysis were carried out again to identify the central and non-central elements, feelings, purposes (professional, social and personal) as well as coherence (or not) of their arguments. At this stage, the frequency with which each element appeared as well as the feelings related to them (alongside their meanings and their relations/implications) were also evaluated, while examining how feelings were integrated and organized the reasoning. In the third stage, an interpersonal and collective analysis was carried out to obtain the most significant contents for the analysis by identifying similarities and differences among the participants' responses, paying attention to each of the aspects raised in the previous stages. At this stage, some of categories of the analysis were outlined to support the identification of the organizing models. In the fourth and last stage, based on the analyses carried out in previous stages and considering the similarities in the dynamics of the organizing models of thinking of the participants, the grouping and identification of the applied organizing models was performed. For this, similar reasonings were grouped together, evidenced by the implications/relationships established by young people when conceiving purposes. Thus, without using previous categories, the authors analyzed and described the dynamics of the organizing models of thinking, which consisted of the organizing models of the young participants, revealing the profiles of their purposes.

\section{Results}

From the analysis carried out, we identified six organizing models of thinking of the young Brazilians, which reflect the different ways of thinking about their purposes.

\section{Organizing Model 1 - ‘Natural’ life progression}

In the first organizing model, the answers present strong contradictions and few meanings were attributed to the elements: family and work, which are important references for everyday life and goals for a distant, stable and peaceful future, were mentioned in a general and vague way. Young people are not engaged in their life purposes and the idealization of a 'good' life is marked by an idea of 'natural' progression without greater expectations and weak intentions regarding the future and, consequently, little perspective of their role in the world. The feelings of happiness and well-being related to these elements were identified and they were related to how they feel in their daily lives and how they expect to feel in the interpersonal relationships established at work and with family.

As an example, Anita2, a 15 year-old girl, when asked about her life in five years' time, replied: "If I am still alive, I will be attending college and I will live in my own home". At 40, Anita imagines herself "old,

$\boldsymbol{\nabla} \nabla \boldsymbol{v}$

2 All names used in the examples are fictitious. 
I don't know what it will be like, I will certainly be working, and I will have a family". Regarding her feelings about the future, her answers are vague, although she believes she will be fine: "I will be great, happy, and fulfilling my desires".

\section{Organizing Model 2 - Future idealization}

Model 2 was applied to the young people who also focused on work and family, as idealized and distant goals from reality. They did not show significant engagement actions and addressed vague plans and dreams related to work and family. They projected a life without problems, without demonstrating shortand long-term goals or concern for the world beyond-the-self. The responses throughout the interview demonstrate a lack of integration of the elements and feelings (happiness, achievement, and well-being) with meanings related to the distant future.

As an example of this organizing model, Fausto, 16 year-old, shared his plans for the near future: "I will be working in the field in which I was trained for, trying my best to succeed, that is, my life will be good and I might even have a family". When he imagines himself at the age of 40 , he thinks he will be "a successful family man, trying to give my children what I never had as a child, educating them not to deviate from the right path and slowly preparing for retirement, keeping my family, work, personal health and well-being in mind". Fausto's projections do not provide details or further meanings; instead, he shares a general, idealized vision of his future.

\section{Organizing Model 3 - Consumerism and financial stability}

Having sufficient money, financial stability and a comfortable life were the goals pointed out by these participants that led them to engage and set goals with the central elements work and education. The individuals attribute the real source of happiness and well-being to financial achievements. It is important to highlight that the attributed meanings have a view centered on the self. The feeling of tiredness, foreseen by them as something to be felt in the future, suggests effort at work towards the desired achievements.

Rosane, 16 year-old, reports that she wants to "have a good job, so that I don't have to depend on others, and also achieve my dream, as quickly as possible, which is to buy and pay for my own car". Her purpose is "to study hard, take professional courses that help me to be an entrepreneur and create my company. I want to make a lot of money and, finally, be able to live a good life, to travel without any worries about the future".

\section{Organizing Model 4 - Work for family support}

In this model, young people combined the elements of work and family. The main meaning attributed to the elements was financial stability to provide for and maintain their family. Personal interests are combined with family members with a future intention that will impact other people. For these young people, there is a sense of duty towards the happiness and well-being of the family, which must be achieved through engagement and goals related to hard work and education.

To exemplify this model, we chose the responses of Andrea, 16 year-old, who has the following expectations for her future: "I'm going to graduate from medical school. I will certainly have a more peaceful life because I will not have to work, as I will use my savings to study". Work does not mean making money

6 for her own benefit but rather to help the family. She predicts her life at 40 as "a fulfilled life, a job. I will 
provide for my family. I will get married and that will be important to me". Both the job in general and the specific field she chose to pursue a career are combined to improve the family situation: "I was 4 years old when I decided to become a doctor. I was 8 years old when I faced a difficult situation in my family. Since then, my purpose is to become rich to get my family out of misery. So, for me, it is important to offer a good quality of life to my grandmother, my mother and my brother".

\section{Organizing Model 5 - Work as social acknowledgement}

In model 5, work itself is the main purpose in life and a source of satisfaction, happiness and wellbeing. It requires effort and perseverance, particularly regarding education, to achieve the participants goals, which demonstrates their commitment and construction of short- and long-term goals. The feeling of accomplishment is related to their professional success achieved through perseverance and personal effort. Happiness is mentioned in relation to social acknowledgement for their efforts. The meaning of social acknowledgement, which combines elements and the feeling of happiness, indicates how these young individuals think about their connection with the world and the impact of their actions on the future.

As an example, 16-year-old Cesar showed to be highly engaged: "I am going to work and go to graduate school. In five years, I want to be independent, start working and be in the world that I want to create". Imagining himself at the age of 24 , he points out: "It may sound funny and mean, but I will be famous. I will be working with great people and my name will be well known. It is true that life will be stressful and tiring because I will have to work hard [...] but my goal is to become a fashion artist, to dress important people, and share my ideas with the world". This young man showed to be focused on professional achievements.

\section{Organizing Model 6 - Altruistic intentions through social actions or work}

Of the 560 young people interviewed, 22 (3.93\%) had altruistic intentions, in addition to goals focused on work and family. Thus, they clearly emphasized a beyond-the-self perspective through which they plan to impact society by doing voluntary or professional work. The motivating element - caring for others -, drives the desire for altruistic actions, leading young people to view work and family as related to these actions. The feelings of accomplishment and happiness refer to their present actions, which involves social causes and/or education as well as achieving long-term goals. The feeling of gratitude, usually towards family, also appears in their responses and it engages the individuals in their short-term actions and goals.

Kleber, 16 year-old, projected his future positively: "I believe that my life will be better, and I have future plans. I want to be an excellent firefighter, to work to prevent people from losing their lives, like my mother [...] the reason why I want to be a firefighter is to help other people. I want to save lives and I will risk my life to save others". He also thought deeply about the impact of his actions on people when he reaches his 40s: "My life will be hectic. I will work to take care of my family, my father (in honor of everything he has done for me), my brother and my children. I will teach my children to help others".

Table 1 shows the number of young people participating for each organizing model of thinking. The results called "others" refer to different thinking dynamics in relation to the models described. These interviews focused on diverse elements, such as God, family, religion, interpersonal relationships, knowledge, and political engagement, but they did not allow us to group them together to reveal profiles of purposes. 
Distribution of participants according to organizing models

\begin{tabular}{|c|c|c|}
\hline Organizing models & $N$ & $\%$ \\
\hline Model 1 & 178 & 31.78 \\
\hline Model 2 & 147 & 26.25 \\
\hline Model 3 & 21 & 3.75 \\
\hline Model 4 & 107 & 19.11 \\
\hline Model 5 & 41 & 7.32 \\
\hline Model 6 & 22 & 3.93 \\
\hline Others & 44 & 7.86 \\
\hline Total & 560 & 100.00 \\
\hline
\end{tabular}

\section{Discussion}

The analysis carried out from the perspective of the theoretical-methodological approach of these investigations can contribute to the understanding of the purposes of young Brazilians. The dynamics of thought organization of these young people were analyzed within six organizing models of thinking. Despite having presented practically the same elements (work and family) and essentially projecting the same feelings (well-being, happiness and accomplishment), they did so in different ways when projecting the future, that is, by attributing meanings and establishing relationships. The feelings received meanings that were linked to the central elements, forming complex relationships in young people reasonings, which reinforces the idea that thoughts and feelings are highly integrated in the human psyche (Moreno-Marimón \& Sastre, 2010; Pinheiro \& Arantes, 2015).

Taking these aspects into consideration, we came to understand the results in light of the concept of purposes used in the present study to outline the profile of the purposes of the young people participating in the studies. By integrating the dimensions of intention/goals, meaningful engagement, and desire to connect and impact the world beyond-the-self (Bronk, 2012, 2014; Malin et al., 2013; Malin, 2018), Table 2 summarizes how these dimensions appear in the models through the elements and meanings attributed to each model.

Table 2 shows that young people in Model 1 understand their lives as a 'natural' progression, providing a perspective in which goals are not strongly presented and, therefore, fail to motivate and organize their lives. Those in Model 2 have strong intentions about the future but are far from having significant engagement and concrete goals that organize the lives of young people. Despite focusing on the family, the adolescents in Model 2 focus on 'having' a family, as a source of personal success in the future, distancing themselves from the purpose of having an impact on the lives of others. Those in Model 3 pursue goals that guide engagement and commitment to short- and long-term goals but are highly centered on the self (consumerism and financial stability). Those in Models 4, 5 and 6 show clear goals in relation to the future, with content focused on family and society, which guide the lives of young people and lead them to commit to short- and long-term goals. In these models, but especially in Model 6, participants show elements, feelings, and meanings, which integrate the three dimensions, strengthening purposes of these young people.

The results show that about $60 \%$ of the young participants understand their purposes as a natural course of life or as a dream or idealization, without engaging in concrete actions or goals to accomplish what they aim for (Models 1 and 2). The limited goals as well as high idealization do not guide the lives of young people, but can rather lead them to existential emptiness, as suggested by the literature (Bronk, 2014; 8 Damon, 2009; Frankl, 1946/1991). In addition, grouping models 1, 2 and 3 together, with approximately 
Table 2

Dimensions of purpose in the organizing models of the young participants

\begin{tabular}{|c|c|c|c|c|}
\hline Models & Intentions/Goals for the future & $\begin{array}{l}\text { Meaningful } \\
\text { engagement }\end{array}$ & $\begin{array}{l}\text { Desire to connect or impact the } \\
\text { world beyond-the-self }\end{array}$ & Feelings \\
\hline Model 1 & $\begin{array}{l}\text { Elements/ meanings did not } \\
\text { appear in this dimension. }\end{array}$ & $\begin{array}{c}\text { Elements/ meanings } \\
\text { did not appear in this } \\
\text { dimension. }\end{array}$ & $\begin{array}{l}\text { Elements/ meanings did not appear } \\
\text { in this dimension. }\end{array}$ & $\begin{array}{l}\text { Well-being and happiness } \\
\text { on daily routine, and } \\
\text { desirable for the future. }\end{array}$ \\
\hline Model 2 & $\begin{array}{l}\text { Family, meant as a source of } \\
\text { success in the future, and work, } \\
\text { which favors financial stability } \\
\text { and a peaceful future life. }\end{array}$ & $\begin{array}{l}\text { Elements/ meanings } \\
\text { did not appear in this } \\
\text { dimension. }\end{array}$ & $\begin{array}{l}\text { Elements/ meanings did not appear } \\
\text { in this dimension. }\end{array}$ & $\begin{array}{l}\text { Desirable happiness, } \\
\text { fulfillment and well-being } \\
\text { for the future. }\end{array}$ \\
\hline Model 3 & $\begin{array}{l}\text { Work, as a way to have a } \\
\text { financially comfortable life and } \\
\text { obtain consumer goods. }\end{array}$ & $\begin{array}{l}\text { Related to study, } \\
\text { meaning as a way to } \\
\text { get the job they want. }\end{array}$ & $\begin{array}{l}\text { Elements/ meanings do not appear } \\
\text { in this dimension. }\end{array}$ & $\begin{array}{l}\text { Well-being and happiness } \\
\text { when projecting future with } \\
\text { financial stability; tiredness } \\
\text { when indicating overwork } \\
\text { and possible physical/ } \\
\text { psychological consequences. }\end{array}$ \\
\hline Model 4 & $\begin{array}{l}\text { Family, which demands } \\
\text { responsibility, and work, which } \\
\text { provides financial stability } \\
\text { to family support, as well as } \\
\text { favoring a good life. }\end{array}$ & $\begin{array}{l}\text { Related to study, } \\
\text { meaning as a way to } \\
\text { get the job that will } \\
\text { support the family. }\end{array}$ & $\begin{array}{l}\text { Retribution to the family for } \\
\text { support and affection through } \\
\text { work. }\end{array}$ & $\begin{array}{l}\text { Achievement, happiness } \\
\text { and well-being when } \\
\text { designing future plans to } \\
\text { support family through } \\
\text { work. }\end{array}$ \\
\hline Model 5 & $\begin{array}{l}\text { Work that is meant as a } \\
\text { source of satisfaction for social } \\
\text { recognition. }\end{array}$ & $\begin{array}{l}\text { Related to study, as } \\
\text { a trajectory of effort } \\
\text { and dedication that } \\
\text { will contribute to } \\
\text { the exercise of the } \\
\text { profession. }\end{array}$ & $\begin{array}{l}\text { Social recognition and impact of } \\
\text { work on society. }\end{array}$ & $\begin{array}{l}\text { Achievement, related to } \\
\text { personal efforts in study } \\
\text { and work; happiness and } \\
\text { well-being through the } \\
\text { recognition of future work. }\end{array}$ \\
\hline Model 6 & $\begin{array}{l}\text { The conditions of other } \\
\text { people, who need help and } \\
\text { care, and who can be supported } \\
\text { through work and/ or social } \\
\text { actions, which make altruistic } \\
\text { actions feasible. Family as } \\
\text { deserving of a legacy and to } \\
\text { whom the education received } \\
\text { should be returned. }\end{array}$ & $\begin{array}{l}\text { Related to social } \\
\text { actions and daily } \\
\text { concerns, as } \\
\text { well as personal } \\
\text { commitment and } \\
\text { studies that favor } \\
\text { the exercise of the } \\
\text { profession. }\end{array}$ & $\begin{array}{l}\text { Carrying out altruistic actions } \\
\text { through work and social actions; } \\
\text { support family. }\end{array}$ & $\begin{array}{l}\text { Happiness, through } \\
\text { acting in social actions, } \\
\text { and achievement, from } \\
\text { altruistic actions projected } \\
\text { through work and social } \\
\text { actions. Gratitude to the } \\
\text { family. }\end{array}$ \\
\hline
\end{tabular}

Note: Words in bold correspond to the elements abstracted by the participants in their responses.

$62 \%$ of participants, there is a high percentage of young people who do not have projects focused on others or on society and their view is highly centered on the self and their own achievements.

Model 4 , which applied to about $19 \%$ of the participants, reveals that the goals focused on family commitment give direction to the lives of young people. The bonds with close people and the willingness to give back to them impact the to these young people's purposes, leading them to an empathetic perspective. Although interpersonal relationships are not evident in Model 5, which applied to about $7 \%$ of the young people, there is an intention to reach out to society, which, in principle, benefits the individuals by being socially acknowledged (Bundick, 2009). These models demystify the idea that the dimension of reaching the world beyond-the-self, an important component of a purpose, must not necessarily focus on altruistic values, but organize young people lives by giving them meaning and enabling them to support others, regardless of the purposes' content (Damon, 2009; Malin, 2018). Anyhow, it is important to point out that only about $4 \%$ of the young people develop purposes based on the needs of society by engaging and establishing concrete goals that are committed to social well-being.

The development of one's purpose is a process highly linked to that of identity formation (Bronk, 2011, 2014; Bundick, 2011). The commitment to personal values and beliefs, established during the interaction of 
individuals with the contexts in which they live, is the crucial point in which identity and purpose meet. The results outline a profile of young people who pointed out work and family, not only as central elements, but also as values by receiving positive affective projections (Araújo, 2003; Pinheiro, 2013). The way in which these values are incorporated into the purposes of these young people receiving meanings that make their daily actions and established goals meaningful, gradually constitute their identities. Likewise, identities committed to such values reinforce and drive significant engagement with purposes (Bronk, 2011).

According to Malin et al. (2013), the intentions or goals outlined by young people are established in social norms. The young Brazilians participating in this study, mostly high school students from public schools, in contexts of social fragility, interact with social issues that involve overcoming the family's economic difficulties, in which 'having' something in the future means success and fulfillment. The distance between an ideal future and the lives of these young people may explain why a large percentage of individuals are not committed to their purposes in life and it may be a promising path for future educational interventions. The meaningful direction that purposes provide to young people and the impact on their lives as well as to the contexts in which they live is accessible to everyone and not a privilege (Malin, 2018). However, young people should receive support and should understand that their purposes can play an important role in overcoming both individual and collective difficulties inherent to the contexts of social fragility (Pizzolato, Brown, \& Kanny, 2011). Education is a fruitful way to strengthen young people's purposes (Damon, 2019; Malin, 2018). Studies (Danza, 2014, 2019; Mariano et al., 2014; Pizzolato et al., 2011) indicate that educational interventions can promote the development of purposes that allow young people to give an ethical sense to their lives and provide them with a steady pursuit of long-term goals combined with present actions and the establishment of meaningful and significant goals for themselves and for the world around them.

\section{Conclusion}

Our results point to the complexity in which Brazilian youth develop their purpose in life and make us revisit the theoretical construct prevalent in the literature, understanding the significant direction within a broader spectrum that considers the interaction with contextual factors and the formation of identities in the youth of our country.

The analysis of life purposes undertaken in this study opens new possibilities for future investigations that can better understand the interactions between contextual and individual aspects in the young Brazilians purposes. In this sense, further research can complement and expand our studies by including a larger number of participants and compare groups from different Brazilian regions, as well as local studies, to unveil these interactions qualitatively in different contexts and, if possible, longitudinally, to better understand the interactions between identity formation and the development of purposes.

Another important research area that has been currently developed is at the intersection between psychology and education to improve our understanding of how educational interventions can favor the development of purposes. We understand that educational practices can support the development of purposes in life, especially for those which, according to the present study, still lack significant goals or need to improve engagement in meaningful goals and actions to help young Brazilians understand their contexts and how they can transform their lives and impact the world they live in.

\section{Contribuition}

All authors equally contributed to the development of this manuscript. 


\section{References}

Andrews, M. C., Bundick, M. J., Jones, A., Bronk, K, C., Mariano, J. M., \& Damon, W. (2006). Youth purpose interview protocol. Stanford: Stanford Center on Adolescence.

Arantes, V. (2012). Modelos organizadores do pensamento e o seu desenvolvimento teórico-metodológico: estudos de Psicologia e Educação (Tese doutorado não-publicada). Universidade de São Paulo, São Paulo. https://doi. org/10.11606/T.48.2013.tde-17092013-102132

Arantes, V., Danza, H. C., Pinheiro, V. P. G., \& Pátaro, C. S. O. (2016). Projetos de vida, juventude e educação. International Studies on Law and Education, 23, 77-94. Retrieved from http://hottopos.com/isle23/77-94Valeria\&.pdf.

Araújo, U. F. (2003). Conto de escola: a vergonha como um regulador moral. São Paulo: Moderna.

Araújo, U. F. (2009). Apresentação à edição brasileira. In W. Damon (Org.), O que o jovem quer da vida? Como pais e professores podem orientar e motivar os adolescentes. São Paulo: Summus.

Bronk, K. C. (2011). The role of purpose in life in healthy identity formation: a grounded model. In J. M. Mariano (Ed.), New directions for youth development. Cambridge: Jossey-Bass.

Bronk, K. C. (2012). A grounded theory of the development of noble youth purpose. Journal of Adolescent Research, 27, 78-109. https://doi.org/10.1177/0743558411412958

Bronk, K. C. (2014). Purpose in life: a critical component of optimal youth development. New York: Springer Science.

Bundick, M. J. (2009). Pursuing the good life: an examination of purpose, meaningful engagement, and psychological well-being in emerging adulthood (Unpublished doctoral dissertation). Stanford University, Stanford.

Bundick, M. J. (2011). The benefits of reflecting on and discussing purpose in life in emerging adulthood. In J. M. Mariano (Ed.), New directions for youth development. Cambridge: Jossey-Bass.

Colby, A., \& Damon, W. (1992). Some do care: contemporary lives of moral commitment. New York: Free Press.

Damon, W. (2009). O que o jovem quer da vida? Como pais e professores podem orientar e motivar os adolescentes. São Paulo: Summus.

Damon, W., Menon, J., \& Bronk, K. C. (2003). The development of purpose during adolescence. Applied Developmental Science, 7(3), 113-128.

Danza, H. C. (2014). Projetos de vida e educação moral: um estudo na perspectiva da teoria dos Modelos Organizadores do Pensamento (Dissertação de mestrado não-publicada). Universidade de São Paulo, São Paulo. https://doi.org/10.11 606/D.48.2014.tde-14102014-112835

Danza, H. C. (2019). Conservação e mudança nos projetos de vida dos jovens (Tese de doutorado não-publicada). Universidade de São Paulo, São Paulo.

Dellazzana-Zanon, \& L., Freitas, L. B. L. (2015). Uma revisão de literatura sobre a definição de projeto de vida na adolescência. Interação Psicologia Curitiba, 19(2), 281-292. http://doi.org/10.5380/psi.v19i2.35218

Erikson, E. H. (1968). Identity youth and crisis. New York: W. W. Norton \& Company Inc.

Erikson, E. H. (1980). Identity and the life cycle (paperback). New York: W. W. Norton \& Company Inc.

Frankl, V. E. (1991). Em busca de sentido: um psicólogo no campo de concentração (15 ed.). Petrópolis: Vozes (Originalmente publicado em 1946).

Gomes, M. A. G. (2016) A dimensão afetiva e a felicidade nos projetos de vida dos jovens: um estudo na perspectiva da Teoria dos Modelos Organizadores do Pensamento (Tese de doutorado não-publicada). Universidade de São Paulo, São Paulo. https://doi.org/10.11606/T.48.2017.tde-15022017-143235

Gonçalo, M. F. (2016). Projetos de vida, felicidade e escolhas profissionais de jovens brasileiros: um estudo na perspectiva da Teoria dos Modelos Organizadores do Pensamento (Dissertação de mestrado não-publicada). Universidade de São Paulo, São Paulo. https://doi.org/10.11606/D.48.2017.tde-22122016-113643

Kashdan, T. B., \& McKnight, P. E. (2009). Origins of purpose in life: refining our understanding of a life well lived. Psychological Topics, 18, 303-316. https://doi.org/2010-23922-008

Kosby, S. I., \& Mariano, J. M. (2011). Promoting youth purpose: a review of the literature. In J. M. Mariano (Ed.), New directions for youth development. Cambridge: Jossey-Bass.

Malin, H. (2018). Teaching for purpose: preparing students for lives of meaning. Cambridge: Harvard Educational Press.

Malin, H., Reilly, T. S., Quinn, B., \& Moran, S. (2013). Adolescent purpose development: exploring empathy, discovering roles, shifting priorities, and creating pathways. Journal of Research on Adolescence, 24(1), 186-199. https://doi. org/10.1111/jora.12051 
Mariano, J. M., \& Going, J. (2011). Youth purpose and positive youth development. In R. M. Lerner, J. V. Lerner, \& J. B. Benson (Eds.), Advances in child development and behavior. Burlington: Academic Press.

Mariano, J. M., Moran, S., Araújo, U. F, Biglia, B. Folgueiras, P., Jiang, F., \& Tirri, K. (2014, October 29). Educating for youth purpose around the world [Video]. YouTube. Retrieved from: http://youtu.be/GM_sziyLOAU

Moran, S. (2009). Purpose: giftedness in intrapersonal intelligence. High Ability Studies, 20(2), 143-159. https://doi. org/10.1080/13598130903358501

Moreno-Marimón, M., Sastre, G., Bovet, M., \& Leal, A. (1998). Conocimiento y cambio: los modelos organizadores en la construcción del conocimiento. Barcelona: Paidós.

Moreno-Marimón, M., \& Sastre, G. (2010). Cómo construimos universos: amor, cooperación y conflicto. Barcelona: Gedisa.

Parks, S. D. (2011). Big questions, worthy dreams: mentoring emerging adults in their search for meaning, purpose, and faith. San Francisco: Jossey Bass.

Pátaro, C. S. O. (2011). Sentimentos, emoções e projetos vitais da juventude: um estudo exploratório na perspectiva da Teoria dos Modelos Organizadores do pensamento (Tese de doutorado não-publicada). Universidade de São Paulo, São Paulo. https://doi.org/10.11606/t.48.2011.tde-10062011-131732

Pinheiro, V. P. G. (2013). Integração e regulação de valores e sentimentos nos projetos de vida de jovens brasileiros: um estudo na perspectiva dos modelos organizadores do pensamento (Tese de doutorado não-publicada). Universidade de São Paulo, São Paulo. https://doi.org/10.11606/T.48.2013.tde-04062013-133059

Pinheiro, V. P. G., \& Arantes, V. A. (2015). Values and feeling in young Brazilians' purposes. Paideia, 25(61), 201-209. doi: 10.1590/1982-43272561201508

Pizzolato, J. E., Brown, E. L., \& Kanny, M. A. (2011). Purpose plus: supporting youth purpose, control, and academic achievement. In J. M. Mariano (Ed.), New directions for youth development. Cambridge: Jossey-Bass.

Seligman, M. E. P., \& Csikszentmihalyi, M. (2000). Positive Psychology: an introduction. American Psychologist, 55(1), 5-14. https://doi.org/10.1037/0003-066X.55.1.5

Velho, G. (1994). Projeto e metamorfose: antropologia das sociedades complexas. Rio de Janeiro: Jorge Zahar.

Winters, C., Leite, J. P. C., Pereira, B. C., Vieira, G. P., \& Dellazzana-Zanon, L. L. (2018). Desenvolvimento juvenil positivo e projetos de vida: uma revisão sistemática da literatura internacional. Cadernos de Educação, 17(35), 39 -53.

Received: March 5, 2020

Final version: September 17, 2020

Approved: November 24, 2020 